\title{
PENGARUH KOMPENSASI DIREKSI DAN RISIKO PERUSAHAAN PADA AGRESIVITAS PAJAK DI INDONESIA
}

\author{
Muhammad Reza \\ Asqolani* \\ Politeknik Keuangan Negara STAN, Jl. Kampus STAN No.12, Banten, Indonesia \\ *asqolani@pknstan.ac.id
}

\author{
ARTICLE INFO \\ Article history: \\ Received March 31, 2021 \\ Revised June 1, 2021 \\ Accepted September 8, 2021
}

Key words:

Corporate Social Responsibility;

Directors Compensation; Firm Risk;

Tax Aggressiveness; Tax Avoidance.

DOI:

https://doi.org/10.33508/jako.v14i1.3111

\begin{abstract}
Research Purposes. This research aims to examine the effect of directors' compensation and firm risk on tax aggressiveness and the role of social responsibility disclosure in moderating this influence.

Research Methods. Data form manufacturing public companies in Indonesia are used with a purposive sampling method from 2016 to 2019 to obtain 58 samples and 232 observations. This study uses two research models, namely the research model without moderation and the research model with moderation.

Research Result and Findings. This research concluded that the compensation for directors and firm risk on tax avoidance has a significant positive effect. In addition to this, corporate social responsibility is also proven to weaken the positive effect of compensation for directors as well as firm risk on tax aggressiveness.
\end{abstract}

\begin{abstract}
ABSTRAK
Tujuan Penelitian. Penelitian ini dilakukan untuk melihat pengaruh dari kompensasi direksi dan risiko perusahaan terhadap agresivitas pajak serta melihat pengaruh laporan tanggung jawab sosial atau corporate social responsibility (CSR) sebagai variabel moderasi.

Metode Penelitian. Data perusahaan manufaktur publik digunakan dengan pendekatan purposes sampling mulai tahun 2016 sampai dengan 2019 dan diperoleh sebanyak 58 perusahaan dan 232 jumlah observasi. Terdapat dua model penelitian yaitu dengan dan tanpa variabel moderasi.

Hasil dan Temuan Penelitian. Hasil penelitian ini menyimpulkan bahwa kompensasi direksi dan risiko perusahaan terhadap penghindaran pajak memiliki pengaruh signifikan positif. Selain itu, laporan tanggung jawab sosial juga terbukti memperlemah secara positif pengaruh kompensasi direksi dan risiko perusahaan terhadap agresivitas pajak.
\end{abstract}

\section{PENDAHULUAN}

Salah satu sumber pendapatan negara yang utama di Indonesia adalah dari sektor perpajakan. Dari data penerimaan negara yang dikutip dari laman kemenkeu.go.id, penerimaan perpajakan hanya mencapai 1.070 triliun rupiah atau $65 \%$ dari total penerimaan negara dalam Anggaran Pendapatan dan Belanja Negara (APBN) tahun 2020. Pajak memainkan peran krusial dalam perekonomian dan pembiayaan operasional negara dengan jumlah yang sangat dominan. Namun, sejak tahun 2009 hingga tahun 2019, target pajak tidak pernah tercapai (Julita, 2021).

Ada beberapa faktor yang dikaitkan dengan penghindaran pajak atau agresivitas pajak, misalnya tanggung jawab direksi terhadap perusahaan dan kompensasi direksi atau manajemen. Berdasarkan otoritas dari pemilik dana atau pemegang saham, direksi melakukan pengambilan beberapa keputusan penting termasuk keputusan penghindaran pajak. Keputusan ini membawa konsekuensi terhadap laba perusahaan dan ukuran kinerja serta kompensasi direksinya. Frank, Lynch, dan Rego (2009) berargumen saat ini terdapat bukti bahwa perusahaan dapat melaporkan laba yang besar dalam laporan keuangan, di sisi lain menyajikan laba kena pajak yang rendah pada laporan fiskal yang diajukan kepada otoritas perpajakan. Desai dan Dharmapala (2006) melakukan penelitian terkait hubungan kompensasi direksi dan penghindaran pajak dan mendapatkan kesimpulan adanya pengaruh negatif kompensasi 
direksi terhadap penghindaran pajak. Sebaliknya, Armstrong, Blouin, dan Larcker (2012) mendapatkan hasil adanya pengaruh positif kompensasi yang diberikan kepada manajemen khususnya kepada direktur perpajakan terhadap penghindaran pajak dengan menggunakan proksi GAAP effective tax rate. Lebih lanjut, Rego dan Wilson (2009) menemukan hasil yang serupa yaitu hubungan positif antara agresivitas pajak dengan tingkat kompensasi direktur eksekutif dan keuangan. Mereka berargumen bahwa pelaporan pajak yang agresif dapat digunakan sebagai strategi untuk mengekstraksi bonus dari perusahaan.

Penelitian terkait kompensasi manajemen terhadap penghindaran pajak di Indonesia mayoritas mendapati hasil hubungan yang negatif antar keduanya (Zulma, 2016; Amri, 2017; Nurfauzi dan Firmansyah, 2018). Mereka mendukung pernyataan Desai dan Dharmapala (2006) yang menyatakan bahwa corporate governance yang kurang baik membuat perusahaan di Indonesia memberikan kompensasi yang tinggi untuk menghindari praktik penghindaran pajak yang berisiko dan hanya menguntungkan sepihak atau manajemen saja. Namun, penelitian tersebut masih menggunakan total kompensasi manajemen yaitu total kompensasi yang diterima direksi dan komisaris ataupun kompensasi total direksi secara agregat. Penelitian ini mengukur kompensasi manajemen dengan hanya menggunakan kompensasi per direksi per tahun karena direksi merupakan pihak yang bertanggung jawab dalam pengambilan keputusan.

Strategi perusahaan dalam meningkatkan laba dapat dilakukan dengan strategi pengurangan biaya (cost-reduction strategy) (Hambrick dan Mason, 1984). Salah satu strateginya dengan pengurangan biaya pajak. Penghindaran pajak merupakan sebuah tindakan yang berisiko bagi perusahaan (Rego dan Wilson, 2012). Beberapa studi menemukan bahwa penghindaran pajak meningkatkan risiko perusahaan seperti volatilitas pengembalian saham yang lebih tinggi (Rego dan Wilson, 2012), premi risiko berbasis industri yang lebih tinggi (Heitzman dan Ogneva, 2019), biaya hutang yang lebih tinggi (Shevlin, Urcan, dan Vasvari, 2013); Hasan, Hoi, Wu, dan Zhang, 2014), dan ketidakpastian pajak yang lebih besar (Dyreng, Hanlon dan Maydew, 2019). Rego dan Wilson (2012) mengungkapkan bahwa perusahaan yang cenderung risk taker akan melakukan berbagai tindakan berisiko termasuk penghindaran pajak. Budiman dan Miharjo (2012); Hanafi dan Harto (2014) melakukan penelitian terkait risiko perusahaan yang menggambarkan karakteristik eksekutif yang digolongkan ke dalam risk taker dan risk averse. Penelitian tersebut menemukan keterkaitan perusahaan dengan karakteristik eksekutif yang bersifat risk taker atau dengan risiko tinggi (volatilitas return yang tinggi) cenderung memiliki hubungan positif terhadap penghindaran pajak. Hasil tersebut mengindikasikan bahwa manajer dengan preferensi risiko risk taker menggunakan strategi penghindaran pajak sebagai salah satu cara untuk meningkatkan angka laba. Di sisi lain, penelitian Damayanti dan Susanto (2015); Dewi dan Sari (2015); Oktamawati (2019) menemukan hasil sebaliknya.

Beberapa literatur juga mengaitkan penghindaran pajak dengan tanggung jawab sosial (Corporate Social Responsibility atau CSR). Tanggung jawab sosial perusahaan (CSR) adalah bentuk tanggung jawab moral perusahaan dan kepeduliannya kepada seluruh stakeholder seperti pemegang saham, konsumen, karyawan, lingkungan, pemerintah, serta komunitas. Tanggung jawab sosial dalam Global Reporting Initiative G4 atau GRI G4 di Indonesia pada indikator pengungkapan, terdapat sub-kategori masyarakat yang menjadi penilaian tingkat pengungkapan CSR yang di antaranya adalah anti korupsi, kebijakan publik, dan kepatuhan terhadap undang-undang. Dengan demikian, tanggung jawab sosial yang rendah (tidak melaporkan) bisa merupakan indikasi adanya penghindaran pajak untuk menutupi hal negatif tersebut. Pernyataan tersebut didukung dengan penelitian Laguir, Staglianò dan Elbaz (2015); Lanis dan Richardson (2012); Ratmono dan Sagala (2015) yang menemukan bukti bahwa adanya pengaruh negatif pengungkapan tanggung jawab sosial terhadap penghindaran pajak.

Albuquerque, Koskinen dan Zhang (2019); Rehman, Khan dan Rahman (2020) berkesimpulan bahwa tanggung jawab sosial berpengaruh negatif terhadap risiko perusahaan. Pengaruh negatif CSR terhadap risiko perusahaan dapat dikaitkan dengan loyalitas pelanggan karena pelanggan bersedia mendukung organisasi dalam kemerosotan ekonomi yang bertanggung jawab secara sosial (McAlister, Srinivasan dan Kim, 2007; Minor dan Morgan, 2011), sehingga hal tersebut dapat mengurangi intensi manajer untuk 
meningkatkan laba melalui penghindaran pajak.

Penelitian ini menggabungkan studi Armstrong, Blouin dan Larcker (2012); Zulma (2016); dan Amri (2017) yang melakukan pengujian atas pengaruh dari kompensasi manajemen terhadap penghindaran pajak yang memasukkan variabel dari penelitian Hanafi dan Harto (2014) yang menguji pengaruh risiko perusahaan terhadap penghindaran pajak. Yang berbeda dengan penelitian sebelumnya adalah menambahkan laporan pengungkapan tanggung jawab sosial (CSR) sebagai moderasi karena berdasarkan studi literatur yang telah dilakukan di berbagai jurnal yang bertemakan penghindaran pajak sebelumnya menyatakan bahwa tindakan penghindaran pajak yang agresif secara sosial tidak bertanggung jawab karena hanya mementingkan keuntungan pribadi atau perusahaan semata.

Dari pernyataan sebelumnya, peneliti menduga aspek tanggung jawab sosial dapat dikaitkan antara kompensasi dan risiko perusahaan dengan penghindaran pajak. Perusahaan akan mengurangi tindakan penghindaran pajak agar dapat bertanggung jawab secara sosial dan mendapatkan keuntungan melalui cara lain. Penelitian ini menggabungkan ketiga aspek yaitu kompensasi direksi, risiko perusahaan, dan pengungkapan tanggung jawab sosial karena ketiga variabel tersebut berkaitan atas keputusan pemilik perusahaan yang mempengaruhi kebijakan eksekutif.

\section{KAJIAN LITERATUR DAN PENGEMBANGAN HIPOTESIS}

Kajian Literatur

Teori Agensi (Agency Theory)

Kontrak keagenan adalah adanya satu pihak yang memiliki dana (principal) yang menggunakan pihak lain (agent) dalam bertindak yang mengatasnamakan pihak pemilik dana. Pihak pemilik dana memberikan otoritas pengambilan beberapa keputusan kepada agent berdasarkan kontrak (Jensen dan Meckling, 1976). Dalam situasi seperti itu, baik principal maupun agent adalah utility maximizer. Mereka berusaha untuk memaksimalkan keuntungan masingmasing. Hal ini merupakan asumsi dasar agency theory. Agent tidak bertindak demi kepentingan utama para principal, melainkan mengutamakan kepentingannya sendiri. Masalah keagenan (Agency Problem) adalah agent yang berperilaku seolah-olah mereka memaksimalkan kesejahteraan principal, padahal nyatanya tidak.
Kompensasi eksekutif merupakan satu cara dalam mekanisme corporate governance untuk menyelaraskan kepentingan shareholders dan manajemen (Barnhart dan Rosenstein, 1998).

Barnea dan Rubin (2010) menganggap keterlibatan CSR sebagai hubungan principal-agent antara manajer dan pemegang saham. Mereka berpendapat bahwa orang dalam yang berafiliasi memiliki kepentingan untuk berinvestasi secara berlebihan (over investment) dalam CSR jika hal itu memberikan keuntungan pribadi dalam membangun reputasi sebagai warga sosial yang baik dengan mengorbankan pemegang saham.

Selain itu, prinsip keagenan juga konsisten dengan Upper Echelon Theory (Hambrick dan Mason, 1984). Teori tersebut menekankan peran top manajemen perusahaan dalam menghasilkan outcome perusahaan baik dari sisi strategi dan efektivitasnya.

Teori Akuntansi Positif (Positive Accounting Theory) Hipotesis Rencana Bonus (Bonus Plan Hypothesis) dikembangkan oleh Watts dan Zimmerman (1990). Pada teori ini, manajer perusahaan dengan mekanisme bonus yang terikat dengan angka akuntansi cenderung mengalihkan laba yang dilaporkan dari periode mendatang ke periode saat ini dalam prosedur akuntansinya. Transfer keuntungan antar periode ini akan berpengaruh pada kepastian dan nominal kompensasi kepada manajer. Hal ini menjadi pembenaran bagi manajer dalam memberikan laporan pendapatan bersih setinggi mungkin karena besaran bonus tersebut tergantung pada besar kecilnya laba perusahaan tersebut.

Pernyataan ini sesuai dengan penelitian pajak yang memberikan bukti bahwa kompensasi mempengaruhi perilaku manajemen untuk cenderung melakukan penghindaran pajak dengan intensi meningkatkan laba perusahaan sehingga kinerja mereka terlihat baik yang tujuannya adalah meningkatkan besaran kompensasi yang diterima oleh manajemen pada kontrak bonus yang diikat pada angka laba setelah pajak atau after tax income dan stock option plan (Phillips, 2003; Rego dan Wilson, 2012).

\section{Teori Pemangku Kepentingan (Stakeholder)}

Teori ini dikembangkan oleh Kujala, Lehtimäki dan Freeman (2019) yang menyatakan bahwa hampir semua entitas yang terpengaruh oleh perusahaan dan proses bisnisnya adalah pemangku kepentingan perusahaan. Pemangku kepentingan perusahaan adalah kelompok- 
kelompok yang tanpa dukungannya organisasi tidak akan ada lagi. Kelompok-kelompok ini mencakup pelanggan, karyawan, pemasok, kelompok aksi politik, kelompok lingkungan, komunitas lokal, media, lembaga keuangan, pemerintah, dan lainnya. Pandangan ini menggambarkan lingkungan perusahaan sebagai ekosistem kelompok yang saling berkaitan yang semuanya perlu dipertimbangkan dan dipuaskan untuk menjaga perusahaan tetap sehat dan berhasil dalam jangka panjang (Kujala, Lehtimäki dan Freeman, 2019).

Salah satu strategi perusahaan untuk memenuhi kepentingan para stakeholder atas informasi non-keuangan perusahaan adalah dengan pelaporan tanggung jawab sosial. Dengan demikian perusahaan dapat meningkatkan dukungan stakeholder dengan pengungkapan tanggung jawab sosial yang lebih baik (Lindawati dan Puspita, 2015).

\section{Agresivitas Pajak}

Hanlon dan Heitzman (2010) mengemukakan tantangan mengenai penghindaran pajak yang belum memiliki istilah dan perhitungan yang universal, penghindaran pajak umumnya disebut dengan tax avoidance atau tax aggressiveness pada banyak penelitian. Ada yang menyatakan bahwa penghindaran pajak lebih tepat kepada istilah tax aggressiveness (Shackelford dan Shevlin, 2001) dan ada pula yang mendefinisikannya sebagai tax sheltering (Weisbach, 2002). Segala jenis aktivitas dan transaksi yang berdampak terhadap penurunan kewajiban pajak perusahaan secara umum dapat dikatakan sebagai penghindaran pajak.

Cheng, Huang, Li, dan Lobo (2010) serta Frank, Lynch dan Rego (2009) mendefinisikan agresivitas pajak sebagai manajemen penurunan pendapatan kena pajak melalui perencanaan pajak. Aktivitas perencanaan pajak ini meliputi aktivitas yang legal, ilegal, atau yang mungkin termasuk dalam wilayah abu-abu. Frischmann, Shevlin, dan Wilson (2008) mendefinisikan penghindaran pajak yang agresif sebagai tindakan yang terlibat dalam pengurangan pajak yang signifikan dengan fakta pendukung yang relatif lemah. Lisowsky (2010) menempatkan agresivitas pajak sebagai serangkaian kegiatan penghindaran yang membentang dari perencanaan pajak yang sah hingga keterlibatan dalam perlindungan pajak yang ilegal. Lietz (2013) berargumen bahwa penghindaran pajak dapat mencakup jenis perencanaan pajak eksplisit yang agresif, bahkan berpotensi melanggar hukum (tax evasion). Lebih lanjut, Lietz (2013) membuat framework hubungan antara tax planning, tax avoidance, tax aggressiveness, tax sheltering, dan tax evasion, istilah tersebut adalah sebuah spektrum aktivitas pengurangan pajak dari yang legal hingga ilegal. Perusahaan yang secara hipotesis memiliki risiko lebih besar dari $50 \%$ kemungkinan (most likely than not) dikoreksi dalam pemeriksaan pajak disebut melakukan tindakan agresivitas pajak (tax aggressiveness).

Konsisten dengan penelitian Frischmann, Shevlin dan Wilson (2008); Lietz (2013); Lisowsky (2010), penelitian ini menggunakan istilah yang sama dengan istilah-istilah dari penelitian tersebut. Dapat disimpulkan, penghindaran pajak yang agresif atau agresivitas pajak adalah tindakan atau aktivitas yang dilakukan dengan intensi mengurangi pajak dengan legalitas yang masih dipertanyakan atau berada di area abu-abu (grey area).

\section{Kompensasi Direksi}

Pengertian kompensasi direksi ini meliputi gaji, bonus, tunjangan, dan pembayaran lainnya yang didapatkan oleh direksi perusahaan selama satu tahun sesuai dengan penelitian Rego dan Wilson (2009) serta Armstrong, Blouin dan Larcker (2012). Besarnya kompensasi yang diberikan pemilik perusahaan kepada direksi dapat berbeda-beda.

Teori Akuntansi Positif sebagaimana dikemukakan oleh Watts dan Zimmerman (1990) menjelaskan tentang kecenderungan manajer perusahaan untuk menggunakan metode akuntansi yang meningkatkan laba perusahaan terkait program bonus (bonus plan). Laba perusahaan itu sendiri digunakan dalam mengukur kinerja perusahaan selain sebagai acuan besaran bonus yang akan diterima oleh manajemen. Sedangkan menurut Chalmers, Koh dan Stapledon (2006), untuk menentukan kualitas kinerja dan keselarasan kepentingan antara pemilik dan manajemen salah satunya dapat diukur dengan tingkat kompensasi direksi yang optimal.

\section{Risiko Perusahaan}

Low (2009) mengklasifikasikan dua karakter perusahaan dalam pengambilan kebijakan mengenai risiko, yaitu risk averse dan risk taker. Perusahaan yang cenderung berani mengambil risiko juga berpeluang untuk mengambil kebijakan-kebijakan yang berisiko. Kebijakan 
perusahaan yang dapat menimbulkan risiko adalah tindakan penghindaran pajak Rego dan Wilson (2012). Beban pajak yang harus dibayarkan dapat menjadi lebih kecil apabila dilakukan penghindaran pajak serta berimplikasi terhadap jumlah kas yang dimiliki perusahaan (Amri, 2017). Hal ini berpengaruh terhadap cash flow yang lebih tinggi sebagai antisipasi untuk menyeimbangkan risiko yang diambilnya (Hanafi dan Harto, 2014). Secara teori keuntungan yang diperoleh seimbang dengan risiko yang dihadapi (high risk-high return).

\section{Tanggung Jawab Sosial (CSR)}

Boone dan Kurtz (2007, dikutip dalam Utama, 2017) mengartikan CSR sebagai upaya manajemen dalam mendukung kewajibannya untuk mempertimbangkan laba, kepuasan pelanggan, dan kesejahteraan masyarakat secara setara. Lain halnya dengan Hoi, Wu dan Zhang (2013) mengartikan CSR sebagai keyakinan tentang tindakan yang dianggap benar dengan memperhatikan tidak hanya masalah ekonomi tetapi juga dampak eksternal sosial dan lingkungan akibat dari tindakan perusahaan. Lebih lanjut, Hoi, Wu dan Zhang (2013) mendefinisikan kegiatan CSR sebagai tindakan korporasi yang mempengaruhi semua pemangku kepentingan perusahaan seperti karyawan, pelanggan, pemegang saham, pemerintah, masyarakat, dan lainnya. CSR merupakan bentuk komitmen perusahaan untuk berkontribusi dalam pembangunan, bertindak secara etis, dan meningkatkan kualitas hidup pekerja serta masyarakat (Wijayanti, Wijayanti dan Samrotun, 2016). Dapat disimpulkan, tanggung jawab sosial perusahaan merupakan cara perusahaan berkomitmen baik bertujuan untuk mencari laba maupun bertanggung jawab kepada pemangku kepentingan secara luas seperti pemerintah, masyarakat, komunitas, pekerja dan pemangku kepentingan lainnya.

\section{Pengembangan Hipotesis}

Adanya asimetris informasi menyebabkan manajemen dapat bertindak oportunis dalam menjalankan tanggung jawabnya. Berdasarkan teori agensi, salah satu cara menghilangkan masalah keagenan adalah dengan mengikat manajemen dengan mekanisme kompensasi (price protection). Jensen dan Meckling (1976) menyatakan bahwa tantangan bagi dewan direksi dan pemegang saham adalah bentuk kombinasi mekanisme kontrol dan insentif apa yang dapat menekan biaya agensi menjadi minimal. Dengan demikian, manajer bisa bertindak secara efektif dan efisien termasuk dalam melakukan penghindaran pajak yang agresif.

Rego dan Wilson (2009) menggunakan data perusahaan dari tiga sumber yaitu data kompensasi $\mathrm{CEO}$ dan $\mathrm{CFO}$ dari database Execucomp, data CRSP untuk menghitung pengembalian saham, dan data lainnya melalui Compustat. Mereka menemukan pengaruh positif kompensasi manajemen terhadap penghindaran pajak. Lebih lanjut, Minnick dan Noga (2010) menemukan keterkaitan kompensasi dalam bentuk pemberian insentif menstimulus manajer melakukan investasi pembayaran jangka panjang misalnya pada manajemen pajak. Manajemen pajak dapat memberikan pengembalian yang lebih tinggi kepada pemegang saham dan berdampak positif. Nurfauzi dan Firmansyah (2018) berargumen bahwa tingginya pemberian kompensasi menstimulus manajemen untuk mengelola perpajakan yang lebih baik. Selain itu, adanya motivasi bonus akibat efisiensi kinerja yang dilakukan dapat membuat manajer melakukan tindakan yang memaksimalkan kepentingan ekonominya (utility maximizer). Dapat disimpulkan dari teori dan beberapa penelitian sebelumnya bahwa kompensasi manajemen mempengaruhi direksi untuk melakukan penghindaran pajak. Hipotesis yang dirumuskan terkait kompensasi dan penghindaran pajak adalah sebagai berikut:

H1: Kompensasi manajemen berpengaruh positif terhadap penghindaran pajak

Perusahaan yang berani mengambil risiko tentunya bertujuan untuk meningkatkan pengembalian atau return. Hal ini didasari dari asumsi klasik manajemen keuangan yang menyatakan risiko tinggi (high risk) akan memberikan pengembalian yang tinggi pula (high return). Beberapa dampak positif yang dapat diperoleh perusahaan yang melakukan kebijakan risk taking yang dikelola dengan baik adalah meningkatkan arus kas, mencapai pertumbuhan yang diharapkan, dan menjadikan perusahaan lebih kompetitif. Di sisi lain, pengambilan kebijakan yang sangat berisiko bisa memberikan dampak negatif seperti kebangkrutan dan juga rusaknya reputasi perusahaan apabila risiko tersebut menyangkut pelanggaran hukum. Salah satu tindakan yang berisiko tersebut adalah penghindaran pajak (Amri, 2017).

Budiman dan Miharjo (2012) yang 
menggunakan tingkat risiko perusahaan untuk mengukur karakter risk taking eksekutif perusahaan menemukan bukti bahwa semakin tinggi tingkat risiko perusahaan juga menimbulkan dampak yang positif terhadap tingkat penghindaran pajak perusahaan. Dari hasil studi tersebut dapat disimpulkan bahwa semakin risk taker perusahaan, akan membuat tingkat penghindaran pajak perusahaan juga semakin besar. Hanafi dan Harto (2014) menemukan hasil serupa, dengan menggunakan data perusahaan BEI mereka menemukan pengaruh signifikan positif antara perusahaan risk taker dengan penghindaran pajak. Di sisi lain, Sugeng, Prasetyo dan Zaman (2020) tidak menemukan pengaruh signifikan antara risiko perusahaan dengan penghindaran pajak. Hipotesis kedua dapat dirumuskan sebagai berikut:

H2: Risiko perusahaan berpengaruh positif terhadap penghindaran pajak.

Teori stakeholder mengungkapkan bahwa tanggung jawab perusahaan untuk memberikan kepuasan dan manfaat bagi semua pemangku kepentingan, bukan hanya bagi pemegang saham. Untuk itu, perusahaan dituntut untuk berperilaku etis dalam segala bidang termasuk pemberian kompensasi. Banyak cara lain yang dapat digunakan oleh eksekutif puncak perusahaan untuk meningkatkan kompensasi mereka (Li dan Thibodeau, 2019). Artinya, eksekutif dapat menggunakan satu atau beberapa cara untuk mencapai tujuan kompensasi pribadi mereka, tetapi tetap menahan diri dari menggunakan semua cara-cara yang tidak etis untuk mendapatkan bayaran yang berlebihan. Tekanan publik memberikan batasan gaji implisit pada total kompensasi tahunan mereka. Mohan, Schlager, Deshpandé dan Norton (2018) menemukan bahwa konsumen menghindari membeli produk dari perusahaan dengan rasio gaji CEO ke pekerja yang lebih tinggi atau dengan kata lain kesenjangan yang tinggi antara atasan dan bawahan. Lebih lanjut, di antara semua alat yang dapat diterapkan manajer untuk mencapai target kompensasi mereka, praktik yang muncul bagi perusahaan untuk menghubungkan kompensasi dengan kinerja tanggung jawab sosial (CSR) perusahaan, yang saat ini dikenal sebagai CSR-contingent compensation yang merupakan alat baru yang dapat digunakan manajer untuk meningkatkan gaji, selain dengan cara-cara tradisional seperti manajemen laba ( $\mathrm{Li}$ dan
Thibodeau, 2019).

Li dan Thibodeau (2019), menemukan hasil pengaruh negatif antara CSR dengan manajemen laba. Selain itu, CSR juga terbukti berpengaruh negatif atas adanya penghindaran pajak. Penelitian oleh Lanis dan Richardson (2012) yang menggunakan sampel dari perusahaan publik Australia sebanyak 408 perusahaan untuk tahun buku 2008-2009 menunjukkan hubungan negatif antara pengungkapan CSR dengan tingkat penghindaran pajak. Oleh sebab itu elemen fundamental dari kegiatan CSR seperti komitmen investasi sosial, dan strategi perusahaan dan CSR (termasuk etika dan perilaku bisnis) dari suatu perusahaan berdampak negatif terhadap penghindaran pajak.

Berdasarkan uraian sebelumnya, dapat disimpulkan bahwa penghindaran pajak merupakan cara tradisional untuk mencapai tujuan kompensasi manajemen dan ada cara-cara lainnya untuk mencapai tujuan kompensasi. Penghindaran pajak juga merupakan perilaku yang akan menurunkan kualitas tanggung jawab sosial perusahaan secara tidak langsung, mengingat tanggung jawab pemerintah salah satunya adalah kesejahteraan sosial bagi seluruh masyarakat melalui program-programnya yang dibiayai oleh pajak. Untuk mempertahankan kualitas pengungkapan tanggung jawab sosial, perusahaan cenderung mempertimbangkan pemberian kompensasi yang besar dan mengurangi perilaku-perilaku tidak etis seperti melakukan penghindaran pajak secara agresif. Dengan demikian, berdasarkan argumenargumen sebelumnya hipotesis ketiga dirumuskan sebagai berikut:

H3: Pengungkapan tanggung jawab sosial perusahaan memperlemah pengaruh positif kompensasi manajemen terhadap penghindaran pajak

Tindakan berisiko yang dilakukan perusahaan memiliki keuntungan terutama bagi pemilik dan direksi apabila risiko yang diambil dapat dikelola dengan baik. Namun, risiko yang terlampau tinggi dapat menempatkan perusahaan pada posisi kebangkrutan. Apabila perusahaan bangkrut, ada dampak sosial yang timbul kepada para pemangku kepentingan seperti karyawan yang kehilangan pekerjaan, kreditur yang gagal dibayar, dan uang yang harus dikeluarkan pemerintah apabila pemerintah memutuskan untuk mem-bailout perusahaan.

Rehman, Khan dan Rahman (2020) dalam 
studi dampak CSR terhadap risiko perusahaan dan performa perusahaan mendapatkan temuan negatif antara pengaruh CSR terhadap risiko perusahaan. Data yang digunakan dalam penelitian tersebut dikumpulkan dari perusahaan Eropa dan Asia yang terdaftar di Fortune's Most Admired Countries untuk periode 2014-2018. Penjelasan yang mungkin untuk pengaruh negatif CSR pada risiko perusahaan dapat dikaitkan dengan loyalitas pelanggan karena pelanggan bersedia mendukung organisasi dalam kemerosotan ekonomi yang bertanggung jawab secara sosial (McAlister, Srinivasan dan Kim, 2007); Minor dan Morgan, 2011). Dengan demikian, perusahaan yang risk taker memiliki pertimbangan lain untuk meningkatkan laba selain dengan menggunakan penghindaran pajak.

Merks (2006) mengasosiasikan tindakan penghindaran pajak sebagai abuse of law/right.
Lebih lanjut, Nugroho (2009) menyimpulkan adanya pemanfaatan celah-celah hukum yang memuat elemen artificiality atau buatan dalam rangka penghindaran pajak. Upaya ini sebenarnya tidak mencerminkan kondisi ekonomi yang sebenarnya atau seharusnya terjadi. Perbuatan tersebut tentunya tidak etis dan bertentangan dengan pengungkapan tanggung jawab sosial yang dinilai dalam standar GRI, yaitu kepatuhan terhadap undang-undang. Berdasarkan uraian sebelumnya, dirumuskan hipotesis sebagai berikut.

H4: Pengungkapan tanggung jawab sosial perusahaan memperlemah pengaruh positif preferensi risiko risk taker perusahaan terhadap penghindaran pajak.

\section{Model Penelitian}

Model penelitian disajikan dalam Gambar 1.

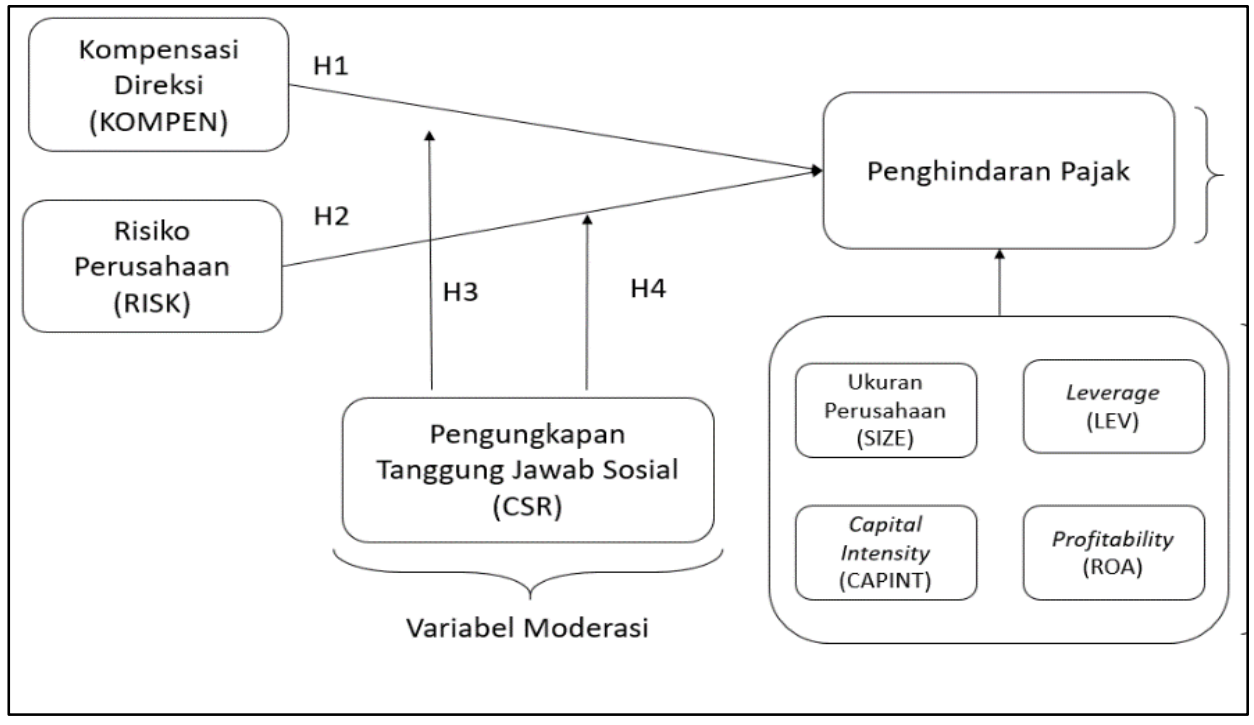

Gambar 1. Model Penelitian

\section{METODE PENELITIAN}

Dalam penelitian ini, metode kuantitatif digunakan untuk menguji teori-teori tertentu dengan cara meneliti hubungan antar variabel yang diukur dengan instrumen tertentu sehingga data yang terdiri dari angka-angka dapat dianalisis berdasarkan prosedur-prosedur statistik (Creswell dan Creswell, 2017). Berdasarkan tingkat penjelasannya, penelitian ini digolongkan dalam penelitian asosiatif yaitu meneliti adanya pengaruh ataupun hubungan antara dua variabel atau lebih (Sugiyono, 2017).

Objek yang dijadikan sampel adalah perusahaan manufaktur. Perusahaan manufaktur dipilih dengan argumen perusahaan manufaktur merupakan sektor penyumbang penerimaan pajak terbesar, yaitu mencapai 29,4\% (Setiawan, Hapsari dan Wibawa, 2018). Namun dari sisi realisasi penerimaan pajak sektor manufaktur hingga akhir Desember 2019 mengalami penurunan sebesar $1,8 \%$ pencapaian tahun sebelumnya yaitu $10,9 \%$. Perusahaan manufaktur juga memiliki transaksi paling kompleks jika dibandingkan dengan jenis perusahaan lainnya dan merupakan jenis perusahaan yang paling umum memiliki afiliasi yang berada di luar negeri (misalnya pabrik atau perusahaan anak) yang pada akhirnya dapat memberikan keleluasaan dalam melakukan skema-skema penghindaran 
pajak seperti thin capitalization, transfer pricing, dan treaty shopping.

\section{Populasi dan sampel penelitian}

Data perusahaan yang digunakan dalam penelitian ini merupakan perusahaan manufaktur yang terdaftar pada Bursa Efek Indonesia (BEI) dari tahun 2016-2019 untuk pengamatan dan 2013-2019 untuk proksi risiko perusahaan. Teknik purposive sampling digunakan dalam pengambilan sampel. Pemilihan sampel dilakukan dengan memilih kriteria perusahaan yang bergerak di sektor manufaktur yang melakukan Initial Public Offering (IPO) sebelum 1 Januari 2012, memiliki laba sebelum pajak positif untuk memastikan adanya skema bonus plan, memiliki data lengkap, dan menggunakan mata uang rupiah. Selain itu, perusahaan yang memiliki data tidak lengkap, baik laporan keuangan maupun laporan tahunan, dikeluarkan dari sampel agar seluruh variabel yang digunakan dapat diukur.

\section{Variabel Penelitian}

Penelitian ini bertujuan untuk menguji pengaruh kompensasi direksi dan risiko perusahaan terhadap agresivitas pajak dengan pengungkapan tanggung jawab sosial sebagai moderasi. Variabel yang digunakan dalam penelitian ini menggunakan empat variabel yaitu agresivitas pajak sebagai variabel dependen, kompensasi direksi dan risiko perusahaan sebagai variabel independen, dan pengungkapan tanggung jawab sosial sebagai variabel moderasi, serta variabel kontrol berupa leverage, ukuran perusahaan (Size), intensitas aset tetap (Capital Intensity), dan profitabilitas (Return on Assets). Variabel kontrol dipilih berdasarkan penelitian Arham, Firmansyah, Nor, dan Vito (2020) tentang studi bibliografi agresivitas pajak di Indonesia yang memberikan bukti bahwa variabel kontrol tersebut memiliki pengaruh dalam banyak penelitian, sehingga dikontrol untuk meningkatkan akurasi model.

Variabel dependen agresivitas pajak diproksikan menggunakan Effective Tax Rate Differential (ETRD) yang pertama kali dirumuskan oleh Hanlon dan Heitzman (2010). Ia menyatakan bahwa ETRD merupakan proksi penghindaran pajak yang tepat yang dapat menangkap perbedaan permanen antara laba akuntansi dan laba fiskal atau Book-Tax Differences (BTD). Frank, Lynch dan Rego (2009) mendasari proksi mereka pada permanen BTD dengan alasan bahwa permanen BTD menunjukkan aktivitas perlindungan pajak yang ideal. Senada dengan pernyataan Frank, Lynch dan Rego (2009), Nurfauzi dan Firmansyah (2018) menyebutkan bahwa proksi penghindaran pajak yang didasari pada BTD dapat menangkap penghindaran pajak baik eksplisit maupun implisit.

ETRD dihitung berdasarkan tarif pajak penghasilan badan (STR) yang diterapkan di suatu negara dikurangi dengan tarif pajak efektif yang dihitung (dibebankan) oleh perusahaan (ETR) dalam laporan keuangan. Angka positif yang dihasilkan ETRD berarti terdapat penghematan pajak yang merupakan indikasi penghindaran pajak dan angka negatif berarti kewajiban pajak tambahan yang harus dibayar perusahaan. Terkait STR, tarif pajak perlu disesuaikan karena keringanan pajak melalui fasilitas pengurangan $\mathrm{PPh}$ memiliki kemungkinan untuk mengurangi tarif pajak efektif. Tarif pajak penghasilan badan dalam negeri yang sahamnya diperdagangkan di Bursa Efek Indonesia adalah sebesar 25\% atau 20\% berdasarkan Peraturan Pemerintah Nomor 77 tahun 2013. Proksi ETRD dalam penelitian ini berdasarkan Amidu, Coffie dan Acquah (2019); Hanlon dan Heitzman (2010); serta Irawan, Kinanti dan Suhendra (2020) yang dirumuskan sebagai berikut.

$$
E T R D=S T R-E T R
$$

Penelitian ini mengukur kompensasi direksi dengan merujuk pada pengukuran yang dilakukan oleh Armstrong, Blouin dan Larcker (2012); Nurfauzi dan Firmansyah (2018) dengan menggunakan logaritma natural total kompensasi direksi saja tanpa melibatkan kompensasi komisaris. Namun, penelitian ini tidak menggunakan kompensasi total untuk seluruh direksi, melainkan perorangan atau per direksi per tahun dengan pertimbangan setiap direksi memiliki target yang berbeda. Variabel independen kompensasi direksi (KOMP) diukur menggunakan Logaritma Natural (Ln) total kompensasi direksi dibagi jumlah direksi dalam satu tahun fiskal, sehingga didapatkan kompensasi per direksi per tahun secara rata-rata. Rerata digunakan karena berdasarkan observasi, kompensasi antar direksi adalah sama kecuali untuk presiden direktur yang jumlahnya tidak jauh berbeda. Proksi kompensasi direksi secara matematis dapat dirumuskan sebagai berikut.

$$
\text { KOMPEN }=\text { Ln } \frac{\text { Total Kompensasi Direksi }}{\text { Jumlah Direksi }}
$$


Variabel independen lainnya yang digunakan dalam penelitian ini adalah risiko perusahaan yang diukur melalui standar deviasi 4 tahunan total sampel (T) dari EBITDA (E) dibagi dengan total aset. Dalam literatur ekonomi dan keuangan, volatilitas return adalah proksi standar yang digunakan untuk menilai risiko dan untuk menangkap tingkat risiko pada keputusan investasi. Perusahaan yang memiliki standar deviasi yang tinggi dibandingkan perusahaan sejenis dianggap memiliki preferensi risiko perusahaan (eksekutif) yang risk taker dan sebaliknya merupakan risk averse apabila memiliki standar deviasi EBITDA yang rendah perusahaan. Perhitungan variabel sesuai dengan penelitian Paligorova (2010); Hanafi dan Harto (2014) dengan rumus sebagai berikut.

$$
R I S K=\frac{\sqrt{\sum_{T=1}^{T} \quad\left(E-\frac{1}{T} \sum_{T=1}^{T} \quad E\right)^{2}}}{T-1}
$$

Variabel moderasi yang digunakan dalam penelitian ini adalah CSR yang diukur dengan menggunakan Corporate Social Responsibility Index (CSRI) yang mengacu pada pedoman instrumen Global Reporting Initiative (GRI) versi GRI Generation 4 (G4). Dalam versi ini, pengungkapan CSR dikelompokkan ke dalam tiga kategori pengungkapan yaitu ekonomi, yang terdiri dari 4 aspek, lingkungan yang terdiri dari 11 aspek, dan sosial yang memiliki 3 sub-kategori yaitu praktik ketenagakerjaan dan kenyamanan bekerja, HAM, dan masyarakat, dengan jumlah total keseluruhan adalah 91 item. Penggunaan proksi GRI G4 menggunakan skala indeks yang diadaptasi dari penelitian yang dilakukan oleh Lee (2017). Indikator tersebut dijadikan acuan untuk menilai pengungkapan CSR dalam laporan tahunan dengan metode pengumpulan data berupa content analysis, untuk kemudian dijumlahkan dan dihitung selanjutnya dengan perhitungan sebagai berikut.

$$
\mathrm{CSR}=\frac{\begin{array}{c}
\text { Total pengungkapan GRI } \\
\text { G4 perusahaan }
\end{array}}{\begin{array}{c}
\text { Jumlah kriteria } \\
\text { pengungkapan GRI G4 }
\end{array}}
$$

\section{HASIL DAN PEMBAHASAN}

Hasil Penelitian

Dengan menggunakan metode purposive sampling atau non-probability sampling, didapatkan beberapa perusahaan yang terdaftar di Bursa Efek Indonesia (BEI) yang sesuai dengan kriteria penentuan sampel. Populasi dalam penelitian ini adalah perusahaan manufaktur pada kurun waktu 2013-2019 untuk proksi risiko dan 2016-2019 untuk periode pengamatan. Sampai dengan akhir tahun 2019, terdapat 675 perusahaan yang listed di bursa efek Indonesia. Selanjutnya dipilih yang memenuhi kriteria dan diperoleh sampel akhir sebanyak 58 perusahaan yang memenuhi kriteria dan dapat diolah. Tahun pengamatan untuk periode pengamatan adalah empat tahun mulai dari 2016-2019, sehingga diperoleh sebanyak 232 firm-years sebagai objek yang diamati. Hasil uji deskriptif dapat dijabarkan dalam Tabel 1.

Tabel 1. Hasil Uji Deskriptif

\begin{tabular}{ccccc}
\hline Variabel & Mean & Med & Max & Min \\
\hline ETRD & -0.0114 & -0.0081 & 5.7983 & -1.8026 \\
\hline KOMPEN $^{*}$ & 3.7092 & 2.4934 & 20.1030 & 0.3455 \\
\hline RISK & 0.0393 & 0.0260 & 0.5961 & 0.0021 \\
\hline CSR & 0.4860 & 0.3736 & 1.9451 & 0.0879 \\
\hline LEV & 0.8074 & 0.5619 & 4.1897 & 0.0833 \\
\hline SIZE & 28.741 & 28.507 & 32.920 & 25.795 \\
\hline CAPINT & 0.3541 & 0.3303 & 0.7966 & 0.0012 \\
\hline ROA & 0.0887 & 0.0585 & 0.9210 & 0.0003 \\
\hline
\end{tabular}


Tabel 2. Hasil Uji Regresi Model 1

\begin{tabular}{cccc}
\hline Variabel & Coeff & t-stat & Prob (one-tailed) \\
\hline C & -0.040 & 4.600 & 0 \\
\hline KOMPEN & 0.014 & 2.952 & $0.000^{* * *}$ \\
\hline RISK & 0.035 & -1.747 & $0.002^{* * *}$ \\
\hline CSR & & \\
\hline KOMPEN*CSR & & \\
\hline RISK*CSR & & 0.041 \\
\hline LEV & -0.002 & -3.980 & 0.000 \\
\hline SIZE & -0.009 & -2.400 & 0.009 \\
\hline CAPINT & -0.026 & 5.033 & \\
\hline ROA & 0.070 & -4.959 & \\
\hline R-squared & & 0.158 & \\
\hline Adj. R-squared & & 0.135 & \\
\hline F-stat & 7.014 & \\
\hline Prob (F-stat) & 0.000 & \\
\hline & & & \\
\hline & & \\
\hline
\end{tabular}

Tabel 3. Hasil Uji Regresi Model 2

\begin{tabular}{cccc}
\hline Variabel & Coeff & t-stat & Prob (one-tailed) \\
\hline C & -0.194 & 9.151 & 0 \\
\hline KOMPEN & 0.020 & 12.305 & $0.000^{* * *}$ \\
\hline RISK & 0.053 & 2.873 & $0.000^{\star * *}$ \\
\hline CSR & 0.229 & -3.210 & 0.0022 \\
\hline KOMPEN*CSR & -0.012 & -1.738 & $0.000^{* * *}$ \\
\hline RISK*CSR & -0.134 & 0.866 & $0.042^{* *}$ \\
\hline LEV & 0.001 & -5.205 & 0.194 \\
\hline SIZE & -0.009 & -3.453 & 0.000 \\
\hline CAPINT & -0.021 & 3.785 & 0.000 \\
\hline ROA & -0.104 & -7.377 & 0.000 \\
\hline R-squared & & 0.404 & \\
\hline Adj. R-squared & & 0.380 & \\
\hline F-stat & & 16.728 & \\
\hline Prob (F-stat) & & 0.000 &
\end{tabular}

Keterangan: *signifikan pada tingkat $10 \%,{ }^{* *}$ signifikan pada tingkat $5 \%,{ }^{* * *}$ signifikan pada tingkat $1 \%$

Penelitian ini menunjukkan kompensasi direksi memiliki pengaruh positif dan signifikan terhadap agresivitas pajak. Selain itu risiko perusahaan juga menunjukkan adanya pengaruh positif dan signifikan terkait agresivitas pajak.

Jika ditambahkan variabel moderasi pada penelitian ini, hasilnya menunjukkan bahwa pengungkapan tanggung jawab sosial memperlemah pengaruh kompensasi direksi terhadap agresivitas pajak. Pengungkapan tanggung jawab sosial juga memperlemah pengaruh risiko perusahaan terhadap agresivitas pajak.

\section{Pembahasan}

Dari hasil pengujian analisis regresi model 1 untuk hipotesis pertama (H1), variabel kompensasi direksi (KOMPEN) berpengaruh positif terhadap agresivitas pajak perusahaan sektor manufaktur. Hasil penelitian ini tidak berbeda dengan penelitian yang dilakukan oleh Minnick dan Noga (2010); Rego dan Wilson (2012); Armstrong, Blouin dan Larcker (2012); Armstrong, Blouin, Jagolinzer, dan Larcker (2015). Namun, penelitian ini bertolak belakang dengan hasil mayoritas penelitian yang dilakukan oleh penelitian di Indonesia, seperti Amri (2017); Zulma (2016); Nurfauzi dan Firmansyah (2018) yang menemukan hasil sebaliknya, yaitu kompensasi berpengaruh negatif terhadap agresivitas pajak. Desai dan Dharmapala (2006) juga menemukan hasil yang berlawanan dari penelitian ini. Penelitian 
yang dilakukan oleh Azizah dan Kusmuriyanto (2016); Kurnia, Pratomo, dan Handoko (2019) juga tidak menemukan pengaruh signifikan kompensasi terhadap agresivitas pajak.

Hal yang membedakan penelitian ini dengan penelitian-penelitian sebelumnya yang dilakukan di Indonesia adalah digunakannya kompensasi direksi per orang bukan gabungan antara kompensasi direksi dan kompensasi komisaris seperti pada penelitian Zulma (2016) dan Amri (2017). Berdasarkan Undang - Undang Nomor 40 tahun 2007 tentang perseroan terbatas, pada pasal 1 ayat 5 dan 6 menjelaskan perbedaan kewenangan antara direksi dan komisaris, dengan demikian sistem governance perusahaan di Indonesia adalah two-tier board. Two-tier board (system) memisahkan manajemen kunci menjadi dua kubu yaitu direksi dan komisaris yang masing-masing memiliki peranan tersendiri, sedangkan pada negara-negara maju seperti Inggris dan Amerika Serikat, perusahaan menggunakan one-tier board yang menggabungkan manajemen kunci ke dalam satu wadah Board of Director (BOD) (Rasyidah, 2013).

Rifai (2009) menyebutkan peranan dewan komisaris dalam pedoman Umum Good Corporate Governance (GCG) Indonesia bagian IVC, yang menyatakan bahwa dewan komisaris bertanggung jawab secara kolektif dalam aktivitas pengawasan dan dalam memberikan nasihat kepada direksi serta memastikan bahwa GCG telah dilaksanakan oleh perusahaan. Dewan komisaris tidak dibolehkan ikut serta dalam pengambilan keputusan operasional. Besarnya kompensasi yang diberikan secara agregat kepada komisaris mengindikasikan banyaknya jumlah komisaris yang ada, sehingga semakin besar kemampuannya untuk melakukan pengawasan kinerja direksi. Lebih lanjut, Eksandy (2017) mengungkapkan bahwa direksi atau manajemen perusahaan dapat didorong oleh komisaris independen untuk mematuhi peraturan perundangan-undangan pajak yang berlaku guna mengurangi risiko.

Secara teoritis, penelitian ini mendukung teori bonus plan hypothesis yang menyatakan bahwa agen, dalam hal ini direksi yang diberi skema bonus (kompensasi), berupaya menggunakan metode akuntansi yang dapat mencapai laba perusahaan mengingat pada umumnya laba masih dijadikan dasar penilaian kinerja perusahaan dan dijadikan dasar untuk memberikan bonus yang akan diterima oleh direksi, sehingga merupakan hal yang lumrah apabila direksi memilih metode-metode yang meningkatkan laba perusahaan termasuk melakukan penghindaran pajak. Hasil penelitian ini juga mengonfirmasi pendapat Godfrey, dkk. (2010) tentang salah satu masalah agensi antara manajer dan pemegang saham. Rajgopal dan Shevlin (2002) menyatakan hal yang senada bahwa perusahaan memberi kompensasi kepada manajer atas penghindaran pajak yang agresif untuk menghargai perilaku pengambilan risiko yang biasanya dihindari manajer. Kinerja keuangan yang dilaporkan dalam laporan keuangan terbukti memiliki pengaruh signifikan atas kenaikan harga saham dalam banyak penelitian sebelumnya (Martani, Mulyono dan Khairurizka, 2009).

Selanjutnya, Desai dan Dharmapala (2006) berargumen bahwa pada perusahaan dengan kualitas tata kelola perusahaan (corporate governance) yang rendah, peningkatan kompensasi manajemen memiliki pengaruh negatif terhadap penghindaran pajak. Manajer cenderung mengutamakan kepentingannya sendiri karena rendahnya pengawasan dan transparansi. Perusahaan yang memiliki kualitas tata kelola perusahaan yang baik memiliki fungsi tata kelola yang berjalan dengan baik pula seperti fungsi audit, pengendalian internal, sistem whistleblowing, remunerasi yang baik serta faktor-faktor lain yang dapat menjadikan tata kelola perusahaan yang baik tetap terjaga (Nurfauzi dan Firmansyah, 2018).

Berdasarkan hasil penilaian ASEAN Corporate Governance Scorecard (ACGS) yang dikutip dari laman setnas-asean.id, Indonesia mengalami peningkatan nilai rata-rata ACGS dari angka $62.68 \%$ pada tahun 2015 ke $70.59 \%$ pada tahun 2017 atau peningkatan sebesar $7.91 \%$. Jika ditelusuri lebih jauh, berdasarkan Asean Corporate Governance Scorecard Country Reports dan Assessments yang diterbitkan pada tahun 2017, Indonesia mengalami peningkatan rata-rata yang cukup tinggi dari tahun 2012 ke tahun 2015. Dengan kenaikan rata-rata sebesar $6.8325 \%$ dari tahun 2012-2017 menandakan Corporate Governance di Indonesia sudah mengalami perbaikan yang signifikan.

Penelitian ini menggunakan data perusahaan BEI yang dimulai dari tahun 2016-2019, sehingga berdasarkan tren peningkatan rata-rata ACGS tahun-tahun sebelumnya dapat disimpulkan tata kelola perusahaan di Indonesia sudah cukup baik. Dari angka perolehan nilai tata kelola perusahaan tersebut, kita dapat mengonfirmasi pernyataan Desai dan Dharmapala (2006) yang menyatakan tata perusahaan kelola yang baik dapat memungkinkan terjadinya efisiensi pemberian kompensasi guna meningkatkan penghindaran pajak. Selain itu, Wilson (2009) juga sependapat dengan pernyataan tersebut dengan mengatakan bahwa kombinasi tata 
kelola yang baik dan penghindaran pajak yang aktif merupakan tanda penyelarasan insentif yang kuat antara manajer dan pemegang saham untuk mengarahkan pada kinerja yang perusahaan yang lebih baik. Dapat disimpulkan, dari hasil regresi model 1 dan pembahasan sebelumnya, penelitian ini memberikan bukti tingginya kompensasi yang diberikan kepada manajemen dapat mendorong manajemen untuk melakukan penghindaran pajak.

Berdasarkan hasil pengujian analisis regresi model 1 untuk hipotesis kedua $(\mathrm{H} 2)$, variabel risiko perusahaan (RISK) berpengaruh positif terhadap penghindaran pajak perusahaan sektor manufaktur. Ini berarti semakin besar risiko perusahaan, semakin besar perusahaan dalam melakukan penghindaran pajak. Risiko perusahaan yang tinggi menandakan karakter eksekutif yang risk taker. Temuan ini sejalan dengan temuan penelitian sebelumnya antara lain oleh Budiman dan Miharjo (2012); Hanafi dan Harto (2014). Disisi lain, temuan ini berbeda dengan penelitian yang dilakukan oleh Damayanti dan Susanto (2015); Dewi dan Sari (2015); Oktamawati (2019); Nabilla dan ZulFikri (2018) yang menemukan hasil sebaliknya, yaitu risiko perusahaan berpengaruh negatif terhadap penghindaran pajak.

Guenther, Matsunaga dan Williams (2017) berpendapat bahwa risiko perusahaan dapat meningkat karena penghindaran pajak dengan alasan tertentu. Pertama, meningkatnya ketidakpastian sehubungan dengan pembayaran pajak masa depan perusahaan karena adanya penghindaran pajak, baik melalui peningkatan ketidakpastian mengenai pemeriksaan oleh otoritas pajak atau transaksi yang mendasari yang menghasilkan penghematan pajak. Kedua, tingkat penghindaran pajak dapat berfungsi sebagai indikator utama mengenai risiko investasi perusahaan di luar yang ditangkap oleh sinyal lain, seperti volatilitas arus kas perusahaan. Penurunan tarif pajak perusahaan dapat mengindikasikan peningkatan investasi di negara yang menggunakan tarif pajak rendah (tax haven) untuk mengimbangi risiko investasi tinggi di negara masing-masing.

Lebih lanjut, beberapa studi menemukan bahwa penghindaran pajak meningkatkan risiko perusahaan yaitu volatilitas pengembalian saham yang lebih tinggi (Rego dan Wilson, 2012), premi risiko berbasis industri yang lebih tinggi (Heitzman dan Ogneva, 2019), biaya hutang yang lebih tinggi (Hasan, dkk. (2014); Shevlin, Urcan dan Vasvari (2013), dan ketidakpastian pajak yang lebih besar (Dyreng, Hanlon dan Maydew, 2019). Namun, ada beberapa penelitian yang kontras dengan hasil penelitian tersebut yang menemukan hasil sebaliknya, yang memberikan bukti bahwa penghindaran pajak dan dua ukuran risiko perusahaan secara rata-rata berhubungan negatif (Goh, Lee, Lim, dan Shevlin (2016); Guenther, Matsunaga dan Williams (2017).

Penelitian ini ditujukan untuk membuktikan pengaruh sebaliknya, yaitu apakah karakteristik eksekutif yang dihitung berdasarkan risiko perusahaan berpengaruh terhadap penghindaran pajak. Kesimpulan yang diperoleh adalah semakin tinggi risiko perusahaan atau semakin risk taker eksekutif di sebuah perusahaan, maka semakin tinggi kemungkinan atau tingkat penghindaran pajaknya. Walaupun beberapa penelitian ada yang menyebutkan bahwa penghindaran pajak meningkatkan risiko perusahaan, sebagian juga menemukan hasil penelitian yang menyatakan penghindaran pajak tidak berhubungan atau malah berpengaruh negatif terhadap risiko perusahaan.

Berdasarkan hasil pengujian analisis regresi model 2 untuk hipotesis ketiga (H3), variabel interaksi kompensasi dan CSR $\left(\mathrm{KOMPEN}^{*} \mathrm{CSR}\right)$ memiliki koefisien negatif signifikan. Jika kita merujuk kepada model 1 koefisien KOMPEN, maka didapat koefisien tersebut bernilai positif. Dikarenakan saling berlawanan, maka dapat disimpulkan pengaruh kompensasi direksi terhadap agresivitas pajak perusahaan sektor manufaktur dapat dilemahkan dengan adanya CSR. Selain itu, hasil tersebut juga menandakan bahwa semakin besar pengungkapan tanggung jawab sosial perusahaan (CSR) akan semakin memperlemah pengaruh positif kompensasi direksi terhadap agresivitas pajak.

Berdasarkan teori sinyal, dengan melakukan pengungkapan CSR, perusahaan dapat memperoleh kenaikan nilai saham dengan cara memberikan keyakinan kepada para investor bahwa perusahaan yang beritikad baik tidak akan melakukan sesuatu yang tidak bertanggung jawab secara sosial. Risikonya dapat merugikan perusahaan itu sendiri, seperti denda perusakan lingkungan, pemboikotan produk, dan ketidakpastian hukum lainnya. Dengan demikian, perusahaan tidak perlu melakukan agresivitas pajak untuk memberikan insentif atau kompensasi yang tinggi kepada direksi.

Godfrey, dkk. (2010) berargumen bahwa untuk memberikan sinyal yang kredibel, sinyal tersebut haruslah mahal dan tidak mudah untuk ditiru kompetitor. Pengungkapan CSR yang tinggi memerlukan biaya yang besar seperti untuk menyewa tenaga penilai, pemberian upah yang 
layak kepada karyawan untuk mengurangi disparitas, dan pengolahan limbah yang sesuai standar. Dengan mahalnya pengeluaran tersebut, perusahaan akan berpikir ulang untuk melakukan agresivitas pajak yang dapat merusak kualitas pengungkapan CSR, terlebih jika perusahaan memberikan kompensasi yang besar kepada direksi. Li dan Thibodeau (2019) mengungkapkan bahwa saat ini ada tekanan sosial dan masyarakat terhadap perusahaan yang memberikan kompensasi berlebihan kepada manajemen. Mohan, Schlager, Deshpandé dan Norton (2018) menemukan bukti bahwa konsumen menghindari membeli produk pada perusahaan yang memiliki kesenjangan tinggi antara gaji CEO dengan para pekerja. Dengan adanya risiko-risiko tersebut, perusahaan yang memiliki kompensasi tinggi dengan pengungkapan CSR yang tinggi akan cenderung mengurangi kegiatan agresivitas pajak agar pengungkapan CSR tetap kredibel dan pemberian kompensasi yang tinggi dapat dijustifikasi.

Menurut Li dan Thibodeau (2019), saat ini target yang diterapkan kepada manajemen tidak lagi hanya menggunakan cara-cara tradisional seperti angka laba saja. Ada pertimbangan lain yang dijadikan dasar dalam memberikan kompensasi kepada direksi. Salah satunya adalah CSR-contingent compensation, yang artinya tujuan atau target atas kontrak kompensasi diformulasikan berdasarkan bobot yang melekat pada pencapaian kegiatan terkait CSR tertentu.

Argumen lain berdasarkan teori agensi yang dapat menjelaskan temuan ini adalah pendapat bahwa direksi yang berafiliasi memiliki kepentingan untuk berinvestasi secara berlebihan (over investment) dalam CSR jika hal itu memberikan keuntungan pribadi dalam membangun reputasi sebagai individu sosial yang baik dengan mengorbankan pemegang saham (Barnea dan Rubin, 2010). Saat reputasi mereka meningkat, direksi akan menikmati lebih banyak peluang berkarir serta memiliki daya tawar yang lebih besar, yang pada akhirnya akan meningkatkan kemampuan mereka untuk menegosiasikan tingkat kompensasi yang lebih tinggi. Berdasarkan pembahasan sebelumnya, pengungkapan CSR yang bersifat melemahkan pengaruh kompensasi direksi terhadap agresivitas pajak dapat dibuktikan.

Dari hasil pengujian analisis regresi model 2 untuk hipotesis keempat $(\mathrm{H} 4)$, variabel interaksi risiko perusahaan dan CSR (RISK*CSR) memiliki koefisien negatif signifikan. Jika kita merujuk kepada model 1 koefisien RISK, maka didapati koefisien tersebut bernilai positif. Dikarenakan saling berlawanan, maka dapat disimpulkan CSR memperlemah pengaruh risiko perusahaan terhadap agresivitas pajak perusahaan sektor manufaktur. Selain itu, hasil tersebut juga menandakan bahwa semakin besar pengungkapan tanggung jawab sosial perusahaan (CSR) akan semakin memperlemah pengaruh positif risiko perusahaan terhadap agresivitas pajak.

Perusahaan mengambil risiko tinggi rentan terhadap masalah kebangkrutan, apabila risiko tersebut tidak dikelola dengan baik (March dan Shapira, 1987). Perusahaan yang mengalami kebangkrutan secara langsung merugikan seluruh stakeholder. Pemerintah tidak mendapatkan kontribusi pajak, investor kehilangan investasinya, dan karyawan yang kehilangan pekerjaan merupakan beberapa dampak dari risiko tersebut. Perusahaan yang melaporkan pengungkapan CSR yang baik serta mengamalkan isi dari CSR tersebut cenderung tidak melakukan agresivitas pajak karena dapat bertentangan dengan isi dalam CSR yaitu kepatuhan terhadap undang-undang. Lebih lanjut, beberapa penelitian berargumen pada perusahaan yang memiliki tanggung jawab secara sosial cenderung memiliki loyalitas pelanggan karena pelanggan bersedia mendukung organisasi dalam kondisi kemerosotan ekonomi (McAlister, Srinivasan dan Kim, 2007); Minor dan Morgan, 2011).

Argumen lain yang dapat menjelaskan pengaruh moderasi pengungkapan CSR terhadap risiko perusahaan adalah tingkat religiositas masyarakat di Indonesia. Ramasamy, Yeung, dan $\mathrm{Au}$ (2010) menguji pengaruh religiositas dan nilainilainya terhadap dukungan tanggung jawab sosial perusahaan (CSR) di kalangan konsumen di Hong Kong dan Singapura. Mereka menemukan bahwa konsumen yang mengaku dirinya sebagai orang yang religius mendukung adanya praktik CSR dan lebih bersedia untuk membeli barang dan jasa kepada perusahaan yang memiliki tanggung jawab secara sosial. Dengan demikian, perusahaan yang risk taker memiliki pertimbangan lain untuk meningkatkan laba selain dengan menggunakan agresivitas pajak.

\section{SIMPULAN}

Hasil analisis yang dilakukan memberikan beberapa kesimpulan terkait variabel-variabel yang diteliti. Kompensasi direksi berpengaruh positif signifikan terhadap agresivitas pajak. Skema kompensasi direksi merupakan sebuah alat yang digunakan pemilik perusahaan untuk melakukan price protection agar direktur tidak bertindak 
oportunis termasuk dalam melakukan agresivitas pajak. Perilaku direksi dan pemegang saham (pemilik) ini sejalan dengan teori bonus plan hypothesis dan agency theory dalam hubungan management-shareholders. Risiko perusahaan berpengaruh positif signifikan terhadap agresivitas pajak. Karakteristik eksekutif risk taker yang ditandai dengan tingginya risiko perusahaan (volatilitas return) cenderung akan melakukan agresivitas pajak dikarenakan keuntungan yang didapatkan dari agresivitas pajak.

Pengungkapan tanggung jawab sosial memperlemah pengaruh kompensasi direksi terhadap agresivitas pajak. Perilaku tersebut sesuai dengan teori stakeholder, legitimasi, dan sinyal. Dari sisi manajemen, pengungkapan CSR yang tinggi mengindikasikan bahwa perusahaan menggunakan kontrak CSR-contingent compensation atau pengikatan skema bonus manajemen kepada pengungkapan CSR, sehingga menurunkan intensi manajemen untuk mendapatkan kompensasi melalui agresivitas pajak. Pengungkapan tanggung jawab sosial memperlemah pengaruh risiko perusahaan terhadap agresivitas pajak. Di samping keuntungan yang didapatkan, agresivitas pajak memiliki risiko tersendiri yaitu timbulnya potensi kerugian yang dapat mengarah pada kebangkrutan perusahaan. Perusahaan yang melakukan pengungkapan CSR yang tinggi, cenderung tidak melakukan agresivitas pajak karena tidak sesuai dengan esensi yang ada di dalam CSR sekaligus untuk menjaga kredibilitas pengungkapan CSR. Perusahaan dapat mencari keuntungan melalui CSR dengan meningkatkan loyalitas dan jumlah pelanggan, sehingga perusahaan yang risk taker memiliki pertimbangan lain untuk meningkatkan laba selain dengan menggunakan agresivitas pajak.

Keterbatasan penelitian ini antara lain periode penelitian ini hanya terbatas pada interval waktu observasi dari tahun 2016-2019 dan hanya menggunakan sektor manufaktur yang terdaftar di perusahaan BEI, sehingga berpotensi kurang menggambarkan efek perubahan antar waktu dan antar perusahaan. Selain itu, peneliti menggunakan pengukuran kompensasi direksi dengan menggunakan asumsi proporsi bagian direksi dibagi dengan jumlah anggota direksi perusahaan, sehingga dalam hal ini seluruh kompensasi per direksi adalah sama, terlepas dari jabatan mereka. Hal ini dapat mengakibatkan nilai kompensasi bagi tiap-tiap individu direksi kurang menggambarkan kompensasi sesungguhnya yang diterima direksi dalam satu tahun. Lebih lanjut, pengungkapan tanggung jawab sosial dianalisis menggunakan content analysis yang bersifat subjektif, sehingga angka yang diperoleh dalam penelitian ini terbatas atas pemahaman penulis dan mungkin tidak menggambarkan secara pasti dari pengungkapan CSR perusahaan. Terakhir, dikarenakan data yang tidak tersedia di Indonesia, penelitian ini menggeneralisasi semua perusahaan menggunakan Bonus Plan dalam skema pemberian kompensasi terhadap direksi.

Saran terkait penelitian ini adalah perlunya regulator untuk mempertimbangkan kedua aspek tersebut dalam memilih wajib pajak yang akan diperiksa dan membuat kebijakan yang mewajibkan pengungkapan variabel tersebut. Selain itu, pengungkapan tanggung jawab sosial juga terbukti memperlemah pengaruh positif kompensasi direksi dan risiko perusahaan, dengan demikian regulator juga dapat menjadikan CSR sebagai salah satu aspek pertimbangan penilaian wajib pajak yang patuh dan menekan aturan yang menekankan pada pengungkapan tanggung jawab sosial. Sedangkan bagi perusahaan, penelitian ini dapat dijadikan pertimbangan dalam memberikan skema bonus kepentingan manajemen dan pemilik, termasuk dalam penghindaran pajak. Perusahaan juga dapat mempertimbangkan untuk berinvestasi pada CSR apabila penghindaran pajak dinilai oportunis dan merupakan tindakan berisiko yang tidak menguntungkan bagi pemegang saham.

\section{REFERENCES}

Albuquerque, R., Koskinen, Y., dan Zhang, C. (2019). Corporate Social Responsibility And Firm Risk: Theory and Empirical Evidence. Management Science, 65(10), 4451-4469.

Amidu, M., Coffie, W., dan Acquah, P. (2019). Transfer Pricing, Earnings Management and Tax Avoidance of Firms in Ghana. Journal of Financial Crime, 26(1), 235-259.

Amri, M. (2017). Pengaruh Kompensasi Manajemen Terhadap Penghindaran Pajak dengan Moderasi Diversifikasi Gender Direksi dan Preferensi Risiko Eksekutif Perusahaan di Indonesia. Jurnal ASET (Akuntansi Riset), 9(1), 114.

Arham, A., Firmansyah, A., Nor, A., dan Vito, B. (2020). A Bibliographic Study on IFRS Adoption Research in Indonesia. International Journal of Psychosocial Rehabilitation, 24(7), 94779501.

Armstrong, C. S., Blouin, J. L., dan Larcker, D. F. (2012). The Incentives for Tax Planning. Journal of Accounting and Economics, 53(1-2), 391-411. 
Armstrong, C. S., Blouin, J. L., Jagolinzer, A. D., dan Larcker, D. F. (2015). Corporate Governance, Incentives, and Tax Avoidance. Journal of Accounting and Economics, 60(1), 1-17.

Azizah, N., dan Kusmuriyanto, K. (2016). The Effect Of Related Party Transaction, Leverage, Commissioners and Directors Compensation on Tax Aggressiveness. Accounting Analysis Journal, 5(4), 307-316.

Barnea, A., dan Rubin, A. (2010). Corporate Social Responsibility as a Conflict Between Shareholders. Journal of Business Ethics, 97(1), 71-86.

Barnhart, S. W., dan Rosenstein, S. (1998). Board Composition, Managerial Ownership, and Firm Performance: An Empirical Analysis. Financial Review, 33(4), 1-16.

Budiman, J. dan Miharjo, S. (2012). Pengaruh Karakter Eksekutif terhadap Penghindaran Pajak (Tax Avoidance). (Tesis, Program S2 Ilmu Akuntansi Universitas Gadjah Mada, Indonesia). Didapat dari

http:/ / etd.repository.ugm.ac.id/penelitian/d etail/54398.

Chalmers, K., Koh, P. S., dan Stapledon, G. (2006). The Determinants of CEO Compensation: Rent Extraction or Labour Demand? The British Accounting Review, 38(3), 259-275.

Cheng, C. A., Huang, H. H., Li, Y., dan Lobo, G. (2010). Institutional Monitoring Through Shareholder Litigation. Journal of financial economics, 95(3), 356-383.

Creswell, J. W., dan Creswell, J. D. (2017). Research Design: Qualitative, Quantitative, and Mixed Methods Approaches. California: Sage Publications.

Damayanti, F., dan Susanto, T. (2015). Pengaruh Komite Audit, Kualitas Audit, Kepemilikan Institusional, Risiko Perusahaan dan Return On Assets Terhadap Tax Avoidance. Esensi: Jurnal Bisnis dan Manajemen, 5(2), 187-206.

Desai, M. A., dan Dharmapala, D. (2006). Corporate Tax Avoidance and High-Powered Incentives. Journal Of Financial Economics, 79(1), 145-179.

Dewi, G. A. P., dan Sari, M. M. R. (2015). Pengaruh Insentif Eksekutif, Corporate Risk dan Corporate Governance Pada Tax Avoidance. EJurnal Akuntansi, 13(1), 50-67.

Dyreng, S. D., Hanlon, M., dan Maydew, E. L. (2019). When Does Tax Avoidance Result in Tax Uncertainty? The Accounting Review, 94(2), 179203.
Eksandy, A. (2017). Pengaruh Komisaris Independen, Komite Audit, dan Kualitas Audit Terhadap Penghindaran Pajak (Tax Avoidance) (Studi Empiris Pada Sektor Industri Barang Konsumsi yang Terdaftar di Bursa Efek Indonesia Periode 2010-2014). Competitive, 1(1), $1-20$.

Frank, M. M., Lynch, L. J., dan Rego, S. O. (2009). Tax Reporting Aggressiveness and Its Relation to Aggressive Financial Reporting. The Accounting Review, 84(2), 467-496.

Frischmann, P. J., Shevlin, T., dan Wilson, R. (2008). Economic Consequences of Increasing The Conformity in Accounting for Uncertain Tax Benefits. Journal of Accounting and Economics, 46(2-3), 261-278.

Godfrey, J, Hodgson, A., Tarca, A., Hamilton, J. dan Holmes, S. (2010). Accounting Theory (Edisi ke7). Queensland: John Wiley \& Sons Australia.

Goh, B. W., Lee, J., Lim, C. Y., dan Shevlin, T. (2016). The Effect of Corporate Tax Avoidance on The Cost of Equity. The Accounting Review, 91(6), 1647-1670.

Guenther, D. A., Matsunaga, S. R., dan Williams, B. M. (2017). Is Tax Avoidance Related to Firm Risk? The Accounting Review, 92(1), 115-136.

Hambrick, D. C., dan Mason, P. A. (1984). Upper Echelons: The Organization as a Reflection of Its Top Managers. Academy of Management Review, 9(2), 193-206.

Hanafi, U., dan Harto, P. (2014). Analisis Pengaruh Kompensasi Eksekutif, Kepemilikan Saham Eksekutif dan Preferensi Risiko Eksekutif Terhadap Penghindaran Pajak Perusahaan. Diponegoro Journal of Accounting, 3(2), 11621172.

Hanlon, M., dan Heitzman, S. (2010). A Review of Tax Research. Journal of Accounting and Economics, 50(2-3), 127-178.

Hasan, I., Hoi, C. K. S., Wu, Q., dan Zhang, H. (2014). Beauty Is In The Eye Of The Beholder: The Effect of Corporate Tax Avoidance on the Cost of Bank Loans. Journal of financial economics, 113(1), 109-130.

Heitzman, S. M., dan Ogneva, M. (2019). Industry Tax Planning and Stock Returns. The Accounting Review, 94(5), 219-246.

Hoi, C. K., Wu, Q., dan Zhang, H. (2013). Is Corporate Social Responsibility (CSR) Associated With Tax Avoidance? Evidence From Irresponsible CSR Activities. The Accounting Review, 88(6), 2025-2059. 
Irawan, F., Kinanti, A., dan Suhendra, M. (2020). The Impact of Transfer Pricing and Earning Management on Tax Avoidance. Journal of Talent Development and Excellence, 12(3), 32033216.

Jensen, M. C., dan Meckling, W. H. (1976). Theory of The Firm: Managerial Behavior, Agency Costs and Ownership Structure. Journal Of Financial Economics, 3(4), 305-360.

Julita, L. (2021). Hmm, Sudah 11 Tahun, RI Tak Mampu Capai Target Pajak. Didapat dari https:/ / www.cnbcindonesia.com/news/2020 0108133413-4-128546/hmm-sudah-11-tahun-ritak-mampu-capai-target-pajak, 02 Februari 2021, pukul 12.35 WIB.

Kujala, J., Lehtimäki, H., dan Freeman, E. R. (2019). A Stakeholder Approach To Value Creation and Leadership. Dalam Leading Change In A Complex World: Transdisciplinary Perspectives (h. 123-143). Tampere: Tampere University Press

Kurnia, K., Pratomo, D., dan Handoko, T. (2019). The Effect of CEO Compensation, Independen Director and Audit Quality on Tax Aggressiveness. ACCRUALS: Accounting Research Journal of Sutaatmadja, 3(1), 62-72.

Laguir, I., Staglianò, R., dan Elbaz, J. (2015). Does Corporate Social Responsibility Affect Corporate Tax Aggressiveness? Journal of Cleaner Production, 107, 662-675.

Lanis, R., dan Richardson, G. (2012). Corporate Social Responsibility and Tax Aggressiveness: an Empirical Analysis. Journal of Accounting and Public Policy, 31(1), 86-108.

Lee, K. H. (2017). Does Size Matter? Evaluating Corporate Environmental Disclosure in the Australian Mining and Metal Industry: A Combined Approach of Quantity and Quality Measurement. Business Strategy and the Environment, 26(2), 209-223.

Li, Z. F., dan Thibodeau, C. (2019). CSR-Contingent Executive Compensation Incentive and Earnings Management. Sustainability, 11(12), 112.

Lietz, G. (2013). Tax Avoidance vs. Tax Aggressiveness: A Unifying Conceptual Framework. Working Paper. University of Münster: Münster.

Lindawati, A. S. L., dan Puspita, M. E. (2015). Corporate Social Responsibilty: Implikasi Stakeholder dan Legitimacy Gap dalam Peningkatan Kinerja Perusahaan. Jurnal Akuntansi Multiparadigma, 6(1), 157-174.
Lisowsky, P. (2010). Seeking Shelter: Empirically Modeling Tax Shelters Using Financial Statement Information. The Accounting Review, 85(5), 1693-1720.

Low, A. (2009). Managerial Risk-Taking Behavior and Equity-Based Compensation. Journal of Financial Economics, 92(3), 470-490.

March, J. G. dan Shapira, Z. (1987). Managerial Perspectives on Risk and Risk Taking. Management Science, 11(11), 1404-1418.

Martani, D., Mulyono dan Khairurizka, R. (2009). The Effect of Financial Ratios, Firm Size, and Cash Flow From Operating Activities in the Interim Report to the Stock Return. Chinese Business Review, 8(6), 44-55.

McAlister, L., Srinivasan, R., dan Kim, M. (2007). Advertising, Research And Development, and Systematic Risk of the Firm. Journal of Marketing, 71(1), 35-48.

Merks, P. (2006). Tax Evasion, Tax Avoidance and Tax Planning. Intertax, 34(5), 272-281.

Minnick, K., dan Noga, T. (2010). Do Corporate Governance Characteristics Influence Tax Management? Journal of Corporate Finance, 16(5), 703-718.

Minor, D., dan Morgan, J. (2011). CSR as Reputation Insurance: Primum Non Nocere. California Management Review, 53(3), 40-59.

Mohan, B., Schlager, T., Deshpandé, R., dan Norton, M. I. (2018). Consumers Avoid Buying from Firms with Higher CEO-to-Worker Pay Ratios. Journal of Consumer Psychology, 28(2), 344-352.

Nabilla, S. S., dan ZulFikri, I. (2018). Pengaruh Risiko Perusahaan, Leverage (Debt to Equity Ratio) dan Pertumbuhan Penjualan Terhadap Penghindaran Pajak (Tax Avoidance) (Studi Empiris Pada Perusahaan Manufaktur Subsektor Makanan \& Minuman Yang Terdaftar di BEI Tahun 2014-2017). Prosiding. Seminar Nasional Cendekiawan 2018: Jakarta.

Nugroho, A. D. (2009). Anti-Avoidance Rules di Indonesia Pasca Amandemen UU Pajak Penghasilan. Mimbar Hukum, 21(1), 109-126.

Nurfauzi, R., dan Firmansyah, A. (2018). Managerial Ability, Management Compensation, Bankruptcy Risk, Tax Aggressiveness. Media Riset Akuntansi, Auditing $\mathcal{E}$ Informasi, 18(1), 75100.

Oktamawati, M. (2019). Pengaruh Karakter Eksekutif, Komite Audit, Ukuran Perusahaan, Leverage, Pertumbuhan Penjualan dan Profitabilitas Terhadap Tax Avoidance. Jurnal Akuntansi Bisnis, 15(1), 23-40. 
Paligorova, T. (2010). Corporate Risk Taking and Ownership Structure. Didapat dari https://www.researchgate.net/publication/2 55659778_Corporate_Risk_Taking_and_Owner ship_Structure, 20 Januari 2021, pukul 12:15 WIB.

Phillips, J. D. (2003). Corporate Tax-Planning Effectiveness: The Role of Compensation-Based Incentives. The Accounting Review, 78(3), 847874.

Rajgopal, S., dan Shevlin, T. (2002). Empirical Evidence on The Relation Between Stock Option Compensation and Risk Taking. Journal of Accounting and Economics, 33(2), 145-171.

Ramasamy, B., Yeung, M. C., dan Au, A. K. (2010). Consumer Support for Corporate Social Responsibility (CSR): The Role of Religion and Values. Journal of Business Ethics, 91(1), 61-72.

Rasyidah, R. (2013). Perbandingan Corporate Governance dengan Sistem One-Tier Board di Inggris dan AS Terkait Efektififas Pencegahan Terjadinya Fraud dalam Korporasi. Global $\mathcal{E}$ Policy, 1(1), 11-18.

Ratmono, D., dan Sagala, W. M. (2015). Pengungkapan Corporate Social Responsibility (CSR) Sebagai Sarana Legitimasi: Dampaknya Terhadap Tingkat Agresivitas Pajak. Nominal: Barometer Riset Akuntansi dan Manajemen, 4(2), 16-30.

Rego, S. O., dan Wilson, R. (2009). Executive Compensation, Tax Reporting Aggressiveness, and Future Firm Performance. Working Paper. University of Iowa: Iowa.

Rego, S. O., dan Wilson, R. (2012). Equity Risk Incentives and Corporate Tax Aggressiveness. Journal of Accounting Research, 50(3), 775-810.

Rehman, Z. U., Khan, A., dan Rahman, A. (2020). Corporate Social Responsibility's Influence On Firm Risk and Firm Performance: The Mediating Role of Firm Reputation. Corporate Social Responsibility and Environmental Management, 27(6), 2991-3005.

Rifai, B. (2009). Peran Komisaris Independen dalam Mewujudkan Good Corporate Governance di Perusahaan Publik. Jurnal Hukum IUS QUIA IUSTUM, 16(3), 396-412.

Setiawan, D., Hapsari, R. T., dan Wibawa, A. (2018). Dampak Karakteristik Dewan Direksi Terhadap Pengungkapan Corporate Social Responsibility Pada Perusahaan Pertambangan di Indonesia. Mix: Jurnal Ilmiah Manajemen, 8(1), 1-15.
Shackelford, D. A., dan Shevlin, T. (2001). Empirical Tax Research in Accounting. Journal of Accounting and Economics, 31(1-3), 321-387.

Shevlin, T., Urcan, O., dan Vasvari, F. (2013). Corporate Tax Avoidance and Public Debt Costs. Didapat dari https:// papers.ssrn.com/sol3/papers.cfm?abs tract_id=2228601, 10 Januari 2021, pukul 17:53 WIB.

Sugeng, S., Prasetyo, E., dan Zaman, B. (2020). Does Capital Intensity, Inventory Intensity, Firm Size, Firm Risk, and Political Connections Affect Tax Aggressiveness? JEMA: Jurnal Ilmiah Bidang Akuntansi dan Manajemen, 17(1), 78-87.

Sugiyono, P. (2017). Metode Penelitian Bisnis: Pendekatan Kuantitatif, Kualitatif, Kombinasi, dan $R \mathcal{E}$. Bandung: CV. Alfabeta.

Utama, A. G. S. (2017). Framing Corporate Social Responsibility on the Websites of Company (Mudflow Incident). Archives of Business Research, 5(12), 198-205.

Watts, R. L., and Zimmerman, J. L. (1990). Positive Accounting Theory: A Ten Year Perspective. The Accounting Review, 65(1), 131-156.

Weisbach, D. A. (2002). An Economic Analysis Of Anti-Tax-Avoidance Doctrines. American Law and Economics Review, 4(1), 88-115.

Wijayanti, A., Wijayanti, A., dan Samrotun, Y. C. (2016). Pengaruh Karakteristik Perusahaan, GCG dan CSR Terhadap Penghindaran Pajak. Prosiding. Seminar Nasional IENACO: Surakarta.

Wilson, R. J. (2009). An Examination of Corporate Tax Shelter Participants. The Accounting Review, 84(3), 969-999.

Zulma, G. W. M. (2016). Pengaruh Kompensasi Manajemen Terhadap Penghindaran Pajak Perusahaan dengan Moderasi Kepemilikan Keluarga di Indonesia. Prosiding. Simposium Nasional Akuntansi 19: Lampung. 